\title{
Corporate Governance and Earnings Management in Taiwan: A Quantile Regression Approach
}

\author{
Ching-Wen Chi ${ }^{1}$ \\ Ming Chuan University \\ Ken Hung ${ }^{2}$ \\ Texas A\&M International University \\ Shinhua Liu* \\ University of Southern Mississippi
}

This study examines the effect of family ownership and board independence on earnings management using quantile regression. Based on a large sample of Taiwanese companies, our results show that the effects of family ownership and board independence on earnings management differ across quantiles. Higher family ownership and greater proportion of independent directors affect earnings management positively and negatively respectively for firms in the lower quantile, but not in the higher quantile. Our findings can reconcile the conflicting predictions by the agency and stewardship theories about the effectiveness of family ownership and board independence on earnings management, with implications for regulators.

Keywords: corporate governance, earnings management, family ownership, independent director, quantile regression

\section{INTRODUCTION}

This study aims to investigate the impact of corporate governance on earnings management. Earnings management has received considerable attention from both academics and practitioners in recent years, thus becomes one of the major research issues in financial accounting and management (Chen, Lin, Wang, \& Wu, 2010; Prencipe, Markarian, \& Pozza, 2008; Shu \& Chiang, 2014). Existing empirical studies on earnings management generally limit their attention to large U.S. or U.K. firms with more widely dispersed ownership structures and focus on mitigating traditional principal-agent (PA) conflicts between shareholders (principals) and managers (agents) (Jensen \& Meckling, 1976). Professional managers with superior information have incentives to report financial accounting information that deviates from the substance of economic transactions in order to maximize private benefits at the cost of shareholders (Wang, 2006). By contrast, the ownership of firms outside the U.S. and U.K. is often concentrated, and these firms are often controlled by a family (Chen \& Ho, 2009; La Porta, Lopez-DeSilanes, \& Shleifer, 1999). In family-controlled firms, concentrated family ownership reduces traditional principal-agent conflicts but increases the likelihood of expropriation of minority shareholders by family 
owners; the resulting conflicts between the two groups are generally referred to as principal-principal (PP) conflicts (Miller \& Le Breton-Miller, 2006; Morck \& Yeung, 2003) Because the interests of controlling and minority shareholders are not closely aligned, controlling shareholders are perceived to have strong opportunistic incentives to report accounting information for self-interested purposes, causing the reported earnings to lose credibility to outside investors (Fan \& Wong, 2002). Thus, family ownership could play an important role in explaining corporate earnings management behavior.

As compared to agency theory, stewardship theory provides a very different perspective on family firms. Stewardship theory posits that family executives are supposed to serve as good stewards who believe their wealth is closely linked to that of the firm and other shareholders rather than as agents of the principals (Davis, Schoorman, \& Donaldson, 1997). Consequently, family owners have incentives to produce higher-quality earnings in order to establish a reputation for good treatment of minority shareholders and enable firms to access equity markets (Wang, 2006; Yoshikawa \& Rasheed, 2010). Contradictory predictions from different theories are reflected in prior empirical studies. Some link family ownership to higher earnings quality (Wang, 2006; Prencipe \& Bar-Yosef, 2011), while others reveal empirical support for a negative relationship between family ownership and earnings management (Chaney, Faccio, \& Parsley, 2011; Fan \& Wong, 2002). These papers leave open the question of whether family ownership improves or lowers the quality of reported earnings.

This paper attempts to provide new empirical evidence that helps resolve the mixed findings as to the earnings management effect of family ownership by applying the method of quantile regression. Compared to classical linear regression, which only captures the causality in mean, the quantile regression method is used to reach estimates for different quantile distributions. Therefore, we expect the quantile regression method to help us more fully understand the various relationships between family ownership and earnings management. Using a sample of publicly listed Taiwanese companies, this paper examines the effects of family ownership on earnings management among firms with different levels of earnings management. Yeh, Lee, and Woidtke (2001) find that about 76 percent of Taiwanese listed companies are family controlled. Additionally, Shyu and Lee (2009) find that an average of 71 percent of board seats are controlled by a family group in Taiwanese listed firms. As Young, Peng, Ahlstrom, Bruton et al. (2008) indicate, principal-principal conflicts are characterized by concentrated family ownership and control, poor legal shareholders protection, and weak governance environment. Therefore, Taiwan represents an ideal setting in which to examine the effect of family ownership on earnings management due to its relative high ownership concentration, weak legal systems, and a predominance of family control (Chen, 2014; Chu, 2011). Further, since board composition is a governance mechanism that can clearly reduce agency problems, we also apply the quantile regression method to investigate the extent to which the proportion of independent directors limits earnings management behavior with different quantile distributions. An additional benefit of using quantile regression is that it can mitigate certain statistical problems, such as non-Gaussian error distribution and sensitivity to outliers (Barnes \& Hughes, 2002). As a result, this paper provides can provide additional insight into family firms and improve understanding of the relationship between corporate governance and earnings management.

The remainder of this paper is structured as follows. Section 2 reviews the related literature and develops the research hypotheses. Section 3 presents the research methodology, sample, and data. Section 4 reports the empirical results, and Section 5 concludes the paper.

\section{THEORETICAL BACKGROUND AND RESEARCH HYPOTHESES}

\section{Family Ownership and Earnings Management}

Concentrated corporate ownership structure and the prevalence of family-controlled businesses are typical features of East Asian countries, and Taiwan is no exception (Chen \& Huang, 2014; Haw, Ho, \& $\mathrm{Li}, 2011$; Kuan, Li, \& Liu, 2012). In family-controlled firms, the fundamental agency problem is not the conflict between managers and shareholders, but the conflict between minority shareholders and the controlling owners who may use their concentrated ownership to expropriate the earnings of minority shareholders. However, if family-controlled owners are good organizational stewards, and often 
altruistically represent the interests of the entire organization and its stakeholders for reasons other than economic self-interest, there is no principal-principal problem.

Previous literature has discussed how family ownership affects earnings management activities through its entrenchment and incentive-alignment effects on controlling owners. The entrenchment effect predicts that increasing family ownership may entrench controlling owners into opportunistically managing earnings because concentrated ownership limits accounting information flows to outside investors (Fan \& Wong, 2002). This effect is consistent with the agency-theoretic view that concentrated ownership creates incentives for controlling shareholders to extract private benefits by expropriating minority shareholders' wealth. In contrast, the alignment effect implies that the interests of controlling owners are better aligned with those of corporate and minority shareholders because controlling owners own large blocks of stock and have a sustained presence in the firm. Therefore, controlling families have incentives to report higher-quality financial statements in order to protect the family's reputation and improve the firm's long-term performance. This is similar to the stewardship-theoretic view that family managers and owners behave as good stewards and are motivated to act in the best interest of the entire organization rather than in their self-interest (Davis, Schoorman, \& Donaldson, 1997).

Wang (2006) finds that family ownership is associated with higher earnings quality for a sample of Standard \& Poor's 500 companies, and this result supports the alignment effects of family ownership on the supply of earnings quality. However, Fan and Wong (2002) find that high ownership concentration has an entrenchment effect of reducing financial reporting quality in East Asian countries. In addition, Leuz (2006) documents that foreign firms with cross-listings in the United States have more concentrated ownership structures than U.S. firms, which is likely to reduce firms' reporting quality. A possible explanation of the different findings as to the relationship between family ownership and earnings management may emanate from different features of the institutional environment (Wang, 2006). Yeh and Woidtke (2005) suggest that ownership tends to be more concentrated and agency problems may be more severe in countries with poor shareholders protection. Leuz, Nanda and Wysocki (2003), using data from 31 countries, find that earnings management is more pervasive in economies with less-developed stock markets, concentrated ownership structures, and weak legal enforcement.

While previous studies suggest that a country's institutional environment influences characteristics of firms' reported earnings, this empirical evidence is based on general regression methods that only provide an estimation of the conditional mean of the dependent variable. In fact, the explanatory variables may affect features of the distribution of a dependent variable other than its mean (Gebka \& Wohar, 2013). In the current study, we postulate that the relationships between family ownership and earnings management may well vary depending on the level of earnings management.

The institutional environment in Taiwan, as in many emerging economies, is characterized by high ownership concentration, weak legal enforcement, and corruption (Fan \& Wong, 2002; Wang, 2006; Wang, 2014). As is known from prior literature, these country-level institutional factors increase insiders' ability to expropriate corporate resources for their own benefit and give them higher incentives to carry out accounting fraud and manipulation. Harford, Mansi and Maxwell (2008) suggest that true entrenchment effects require low legal shareholder protection. Consequently, for self-interested reasons, controlling shareholders in firms with low earnings management that have higher family shareholding may try to strengthen their control of accounting reporting policies and limit information content disclosure to the public.

In contrast, when a firm's earnings management is high, this implies that the controlling owner has obtained effective control of the firm. In such circumstances, any increase in owner's share of ownership does not further entrench the controlling owner, but the higher ownership concentration can improve the alignment of interests between the controlling owner and the minority shareholders and reduce the effects of entrenchment (Fan \& Wong, 2002). Yeh, Lee, and Woidtke (2001) argue that "In family-controlled firms with high levels of control, expropriation is less desirable because the families now bear more of the costs for private gain" (p. 23). In light of the aforementioned discussion, we posit that higher family ownership is expected to be associated with high earnings management in firms with low vis-à-vis high earnings management. Accordingly, we formulate the first hypothesis as follows: 
Hypothesis 1. The higher family ownership increases the likelihood of engaging in earnings management for firms with low earnings management but not for firms with high earnings management.

\section{Proportion of Independent Directors and Earnings Management}

In emerging economies where the market for corporate control is weak, internal controls mechanisms become more important for corporate governance (Mak \& Li, 2001). The board of directors is often considered the primary internal control mechanism for mitigating agency conflicts within the firm and improving firm performance (Jensen, 1993; Cueto, 2013). Chen and Liu (2010) suggest that effective monitoring from the board of directors is key to improving the reliability of financial reports due to a conflict of interest between controlling owners and minority shareholders in emerging markets.

Previous studies suggest that the board composition is an important factor in creating a board that effectively monitors management's behavior (Beasley, 1996; Chen, 2014). The boards of directors generally include inside members who are managers of the firm and outside members who are not fulltime employees. While internal managers can be the most influential board members due to the valuable information they have about the organization's activities, the inclusion of inside board members conflicts with the control function of the board (Fama \& Jensen, 1983; Peasnell, Pope, \& Young, 2003). In contrast, outside directors provide expertise and objective advice, help evaluate the firm's projects, and restrain family opportunism (Anderson \& Reeb, 2004; Beasley, 1996; Chen, 2014). Fama (1980) and Fama and Jensen (1983) argue that outside directors have incentives to be effective monitors of managerial actions because they wish to signal their performance as outside directors to external market and at the same time enhance their reputations. Prior empirical evidence generally supports the expectation that the inclusion of larger proportions of independent directors helps reduce the likelihood of earnings management (Klein 2002; Xie, Davidson, \& Dadalt, 2003).

Some commentators argue that dominant families exert significant influence in the appointment of board members (Prencipe and Bar-Yosef, 2011; Young et al., 2008). As discussed in Yeh and Woidtke (2005), a firm's board composition is determined by the controlling shareholders' motivation, especially in countries with weaker investor protection. If controlling shareholders are committed to wellfunctioning corporate governance, they may select more members with professional expertise and without family ties for the board. In contrast, controlling shareholders can strengthen their control by selecting board members who are closely connected to controlling families and more likely to support their decisions.

Beasley (1996) reports that no-fraud firms have significantly higher percentages of outside directors than firms experiencing financial statement fraud. Therefore, when firm earnings management is low, the entrenchment effect of family owners is less likely to occur. In such instances, family owners may enhance their commitment to the organization and enable independent directors to properly perform their monitoring role, and hence limit earnings management behavior. In contrast, entrenched controlling owners are likely to dominate the board and lessen the monitoring role of independent directors when firm earnings management is high. Prior studies argue that board members who are classified as independent but who may have implicit ties to the controlling family or executives appear to weaken the board's monitoring function (Fracassi \& Tate, 2012; Prencipe \& Bar-Yosef, 2011). Additionally, as Leuz, Nanda, and Wysocki (2003) suggest, the pervasiveness of earnings management increases in private benefits and hence reduces the likelihood of outside intervention. As a result, boards of directors are not effective in protecting minority stockholders from expropriation by entrenched family owners in firms with high earnings management. Thus, we expect a higher proportion of independent directors to be more potent in limiting earnings management in firms with low vis-à-vis high earnings management. This leads to our second hypothesis:

Hypothesis 2. A higher proportion of independent directors reduces the likelihood of engaging in earnings management for firms with low earnings management but not for firms with high earnings management. 


\section{RESEARCH METHODS, SAMPLE, AND DATA}

\section{Research Methodology}

Because the goal of this paper is to observe the various relationships between corporate governance and earnings management in Taiwan, a quantile regression model is used to examine the relationship in greater detail. A more traditional approach would use ordinary least squares to estimate a linear regression model; however, this method focuses only on the central tendency of the distribution of the dependent variable. As compared to OLS regression, quantile regression is more robust, rendering separate estimates for all conditional quantiles of the dependent variable's distribution (Ramdani \& Witteloostuijn, 2010). Keonker and Hallock (2001) suggest running a complete set of quantile regressions to explore a comprehensive set of strategies for policy analysis. In addition, quantile regression does not require the strict assumptions that traditional linear regression does, such as Gaussian error distribution and the absence of extreme outliers (Ramdani \& Witteloostuijn, 2010). In this study, we estimate the coefficients at the $10^{\text {th }}, 25^{\text {th }}, 50^{\text {th }}, 75^{\text {th }}$, and $90^{\text {th }}$ quantiles, and hence can obtain a boarder picture of the relationship between corporate governance and earnings management.

In addition, as earnings management and corporate governance determinations are simultaneous, modeling the relationship between the two can incur endogeneity problems if contemporaneous corporate governance and earnings management are used. To control for endogeneity problems, we follow Harford, Mansi and Maxwell (2008) and examine whether the lagged value of the firm's earnings management and governance variables are related to its future earnings management.

\section{Earnings Management Measures}

Because earnings management cannot be observed directly, and because discretionary accruals are believed to better reflect managerial interventions into the financial reporting process, most existing earnings management research employs discretionary accruals as a proxy for earnings management (Chaney, Faccio, \& Parsley, 2011; Islam, Ali, \& Ahmad, 2011). Prior research suggests that management has greater discretion over current accruals and that the variation in total accruals is thus mostly driven by current accruals (Ashbaugh, LaFond, \& Mayhew, 2003). Following Ashbaugh, LaFond, and Mayhew (2003), we use the performance-adjusted current accruals measure, ROA in Estimation Discretionary Current Accruals (REDCA), which focuses on current accruals, as our measure of discretionary accruals. REDCA is calculated by subtracting expected performance-adjusted total current accruals (EPTCA) from total current accruals (TCA). Total current accruals are computed as follows:

$$
\begin{aligned}
\mathrm{TCA}_{\mathrm{i}, \mathrm{t}}= & \Delta(\text { Current Assets })_{\mathrm{i}, \mathrm{t}}-\Delta(\text { Current Liabilities })_{\mathrm{i}, \mathrm{t}}-\Delta(\text { Cash })_{\mathrm{i}, \mathrm{t}} \\
& +\Delta(\text { Short term and Current long term Debt })_{\mathrm{i}, \mathrm{t}}
\end{aligned}
$$

all scaled by beginning-of-period total assets, where Cash is the sum of cash and short-term investments, and Short-term and Current long-term Debt is the portion of financial debt payable within one year, including current portion of long-term debt.

Similar to the Jones and modified-Jones procedures, we estimate REDCA using a two-stage procedure. In the first stage, total current accruals (TCA) are regressed on the change in net sales and lagged ROA, as suggested by Kothari, Leone, and Wasley (2005), for each sample firm with the timeseries data prior to the event years. In the second stage, the estimated parameters from this regression are then combined with event-period data to calculate the expected performance-adjusted total current accruals (EPTCA). To estimate EPTCA, we first estimate the parameters of the following regression:

$\mathrm{TCA}_{\mathrm{i}, \mathrm{t}}=\beta_{1}\left(\frac{1}{\mathrm{~A}_{\mathrm{i}, \mathrm{t}-1}}\right)+\beta_{2}\left(\frac{\Delta \mathrm{REV}_{\mathrm{i}, \mathrm{t}}}{\mathrm{A}_{\mathrm{i}, \mathrm{t}-1}}\right)+\beta_{3}\left(\mathrm{ROA}_{\mathrm{i}, \mathrm{t}-1}\right)+\varepsilon_{\mathrm{i}, \mathrm{t}}$ 
where $\triangle \mathrm{REV}_{\mathrm{i}, \mathrm{t}}$ is the change in net sales for firm $\mathrm{i}$ in year $\mathrm{t}$, and $\mathrm{A}_{\mathrm{i}, \mathrm{t}-1}$ is the beginning of year total assets. Lagged $\mathrm{ROA}_{\mathrm{i}, \mathrm{t}}$ is the net income on assets for firm $\mathrm{i}$ in year $\mathrm{t}-1$, included to control for firm performance. $\beta_{1}, \beta_{2}$ and $\beta_{3}$ are regression coefficients, and $\varepsilon_{\mathrm{i}, \mathrm{t}}$ is the regression residual.

We then use the parameters estimates from Equation (2) to calculate the expected performanceadjusted total current accruals (EPTCA):

$\mathrm{EPTCA}=\widehat{\beta}_{1}\left(\frac{1}{\mathrm{~A}_{\mathrm{i}, \mathrm{t}-1}}\right)+\widehat{\beta}_{2}\left(\frac{\Delta \mathrm{REV}_{\mathrm{i}, \mathrm{t}}-\Delta \mathrm{REC}_{\mathrm{i}, \mathrm{t}}}{\mathrm{A}_{\mathrm{i}, \mathrm{t}-1}}\right)+\widehat{\beta}_{3}\left(\mathrm{ROA}_{\mathrm{i}, \mathrm{t}-1}\right)$,

where $\widehat{\beta}_{1}, \widehat{\beta}_{2}$, and $\widehat{\beta}_{3}$ are the OLS regression estimates of $\beta_{1}, \beta_{2}$, and $\beta_{3}$ respectively, obtained from equation (2), and $\triangle \mathrm{REC}_{\mathrm{i}, \mathrm{t}}$ is the change in receivables during the year in event (in the event period). REDCA, our measure of earnings management, is equal to TCA minus EPTCA.

REDCA $=\frac{T_{C A} A_{i, t}}{A_{i, t-1}}-(E P T C A)$

\section{Experimental Variables}

Corporate governance variables The corporate governance mechanisms investigated in this study include corporate ownership structure and board independence. The variables related to ownership structure and board independence are family ownership and the proportion of independent directors, respectively. Family Ownership is measured by a numerical measure that indicates the percentage of common stock owned by family members, with a larger value indicating greater family interests in the firm. The Independent Directors ratio is measured as the proportion of independent directors relative to the total number of directors on the board. In this study, the identification of independent directors in each company is based on the definition provided by the Taiwan Economic Journal (TEJ).

Control variables To isolate the effects of our test variables on earnings management, we include a number of control variables based on the earning management literature. These control variables include firm size, financial leverage, Market-to-Book ratio, the ratio of operating cash flow to total assets, and sales growth. Firm Size is log of total assets and Leverage is the ratio of financial liabilities to total assets. Market-to-Book ratio is calculated as the market value of equity to its book value. The Cash Flow ratio is measured as the cash flow from operations divided by lagged total assets. This study measures Sales Growth using year-to-year percentage change in total sales. In addition, other ownership and board features, such as institutional ownership and CEO duality, can affect incentives to manage earnings. Thus, we also add institution ownership and CEO duality as control variables. Institution Ownership is the percentage of shares that institutions own in the firm divided by the total number of outstanding shares. CEO Duality is a dummy variable that assumes the value of one if a CEO serves as the chairman of the board and zero otherwise.

\section{Sample and Data}

Our empirical analysis is based on data for all non-financial companies that were publicly listed in the Taiwan Stock Exchange (TSE) from 2005 to 2012. Financial companies are excluded from our analysis because their financial reports are quite different from those in nonfinancial companies (Filatotchev, Lien, $\&$ Piesse, 2005). All the data are obtained from the Taiwan Economic Journal (TEJ) database, which provides the most comprehensive and reliable financial information in Taiwan. Data from the period 2000-2005 are used to estimate the expected performance-adjusted total current accruals (EPTCA). After removing observations with missing total current accruals data, we have 3,687 observations remaining. We further drew 7,941 preliminary firm-year observations from 2006 through 2012. To obtain data for the ROA in Estimation Discretionary Current Accruals (REDCA) analysis, we deleted 263 observations with missing data for total current accruals, and 41 observations with missing values in corporate governance variables (from 2005-2011), which leads to the final sample of 7,637 firm-year observations representing 1,267 unique firms. 
Table 1 provides descriptive statistics of the sample data. We can see that the mean is different from the median and that the skewness coefficient is not close to zero for all variables, meaning that the variables are not symmetrically distributed. In addition, the kurtosis value is above three for several variables, indicating the sample is replete with extreme values. The Shapiro-Wilk W normality test for each variable indicates that we cannot reject the null hypothesis of normal distribution only for the Dual variable $(Z=-0.572, p=0.716)$; the other variables are far from the normal distribution. In sum, quantile regression may be more appropriate than OLS regression for providing more efficient estimators. In Table 1 , average family shareholding is $30 \%$, which implies that family control has a significant influence on Taiwan's listed firms. In addition, the proportion of independent directors is $13.9 \%$ on average, much less than that reported in U.S. studies, in which independent directors usually comprise more than half of all board members (Huang \& Chan, 2013).

TABLE 1

DESCRIPTIVE STATISTICS

\begin{tabular}{llllllll}
\hline & Mean & $\begin{array}{c}\text { Std. } \\
\text { Dev. }\end{array}$ & Median & P25 & P75 & Skewness & Kurtosis \\
\hline REDCA & -0.008 & 0.134 & -0.014 & -0.055 & 0.026 & 15.173 & 580.564 \\
Family Ownership & 0.300 & 0.177 & 0.275 & 0.159 & 0.415 & 0.699 & 3.036 \\
Independent & 0.139 & 0.147 & 0.125 & 0.000 & 0.250 & 0.501 & 2.029 \\
Directors & 15.287 & 1.428 & 15.097 & 14.280 & 16.060 & 0.788 & 3.884 \\
Firm Size & 0.428 & 0.174 & 0.430 & 0.299 & 0.550 & 0.140 & 2.673 \\
Leverage & 14.736 & 19.409 & 11.658 & 7.169 & 18.260 & 31.886 & 1821.505 \\
Market-to-Book & 0.193 & 3.502 & 0.062 & -0.086 & 0.229 & 69.084 & 5331.200 \\
Sales Growth & 0.082 & 0.636 & 0.070 & 0.013 & 0.137 & 76.830 & 6387.574 \\
Cash Flow & 0.359 & 0.222 & 0.324 & 0.177 & 0.516 & 0.507 & 2.427 \\
Institution Ownership & 0.348 & 0.476 & 0.000 & 0.000 & 1.000 & 0.638 & 1.407 \\
CEO Duality & & & & & & & \\
\hline Vaiabledefition
\end{tabular}

Variable definitions:

REDCA = discretionary accruals, estimated using the performance-adjusted current accruals measure

Family Ownership = family ownership based on the percentage of common stock owned by family members

Independent Directors $=$ proportion of independent directors

Firm Size $=$ natural $\log$ of total assets

Leverage $=$ ratio of financial liabilities to total assets

Market-to-Book $=$ ratio of market value of equity to its book value

Sales Growth = year-to-year percentage change in total sales

Cash Flow $=$ cash flow from operation, scaled by lagged total assets

Institution Ownership = institutional ownership based on the percentage of common stock owned by institutional shareholders

CEO Duality $=$ one if a CEO serves as the chairman of the board, zero otherwise.

$\mathrm{P} 25=25^{\text {th }}$ percentile

$\mathrm{P} 75=75^{\text {th }}$ percentile 


\section{EMPIRICAL RESULTS}

\section{Results from Fixed-effect and Quantile Regression Models}

We examine the effects of family ownership and the proportion of independent directors on REDCA using a panel data analysis. Since the results of Hausman test (p-value $=0.000$ ) suggest the adoption of a fixed-effects model, we report the fixed-effects estimation as a reference model and as such provides a comparison of the results to those of quantile regression models. To control for the problem of heteroscedasticity, we correct the standard error for all regression estimates, and report White-adjusted tstatistics for all the coefficients. Table 2 shows the fixed-effects and quantile regression estimates, respectively. The fixed-effects results suggest that family ownership is positively related to earnings management $(\beta=0.095, \mathrm{p}<0.05)$ and that the proportion of independent directors is negatively related to earnings management $(\beta=-0.063, \mathrm{p}<0.05)$. Since the fixed-effects estimator only capture the central tendency of the distribution, this study employs the quantile regression in order to provide a more thorough means of understanding the impact of corporate governance on earnings management.

The other results in Table 2 are from the quantile regression for the 10th, 25th, 50th, 75th, and 90th quantiles. They clearly indicate that the estimated coefficients vary with the quantile levels. We find that the sign of the Family Ownership coefficients is positive and statistically significant at a 5\% level in the quantile (10th and 25th) up to the median level (50th). Beyond the median level, we do not find the Family Ownership coefficients to be statistically significant. This indicates that higher family ownership increases the likelihood of engaging in earnings management for firms with low and median earnings management. However, we failed to find evidence that family ownership is potent in promoting earnings management activities for firms with high earnings management. Therefore, Hypothesis 1 is supported.

Table 2 shows that the coefficients of Independent Directors are negative and statistically significant in the lower quantile (10th and 25th) and insignificantly in the 50th, 75th, and 90th quantiles. This finding supports Hypothesis 2, indicating that the proportion of independent directors is an effective governance mechanism in firms with low earnings management, but is not an effective way to reduce the earnings management behavior of firms with median and high earnings management. 


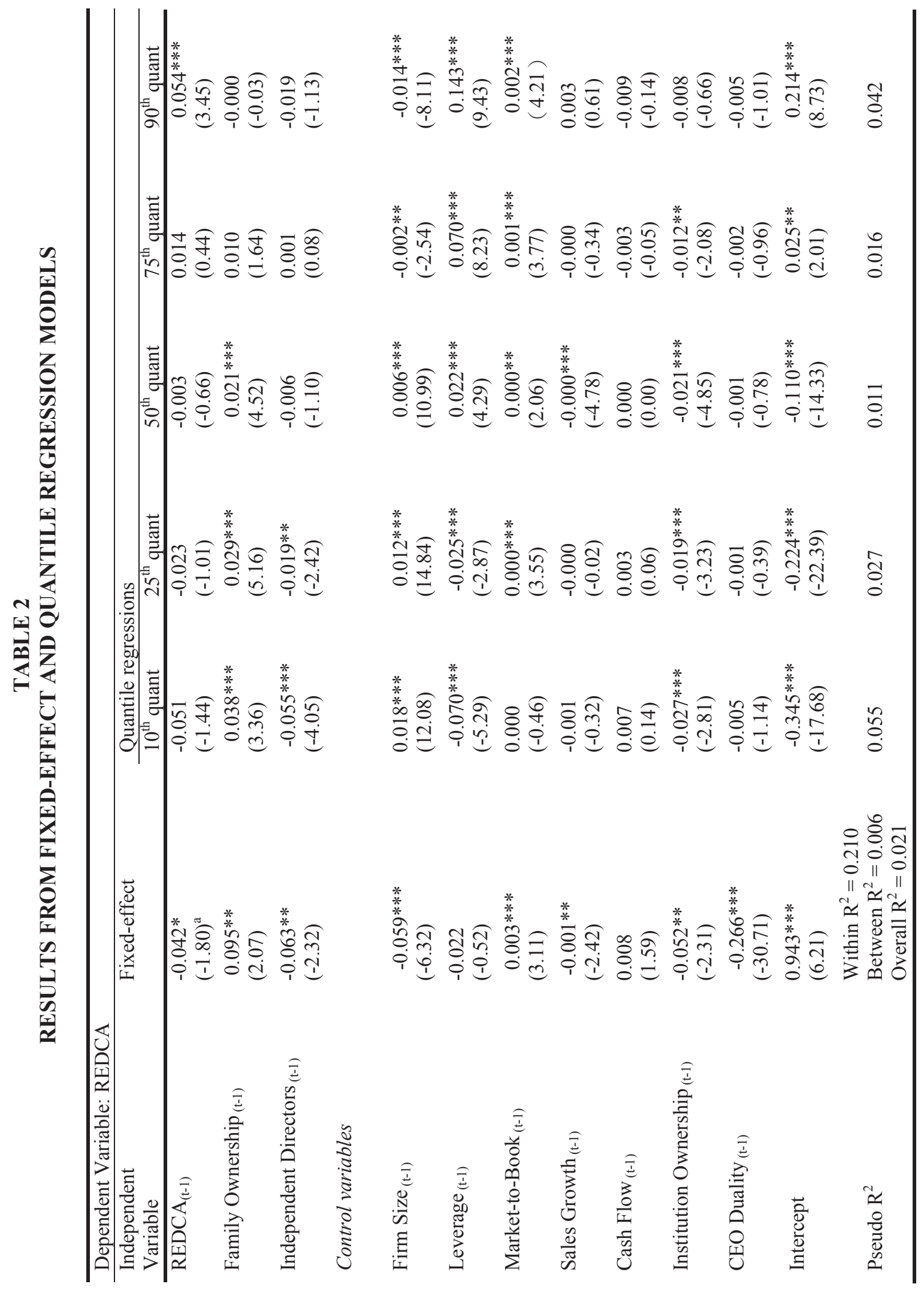

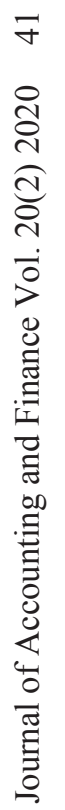


Variable definitions:

REDCA = discretionary accruals, estimated using the performance-adjusted current accruals measure

Family Ownership = family ownership based on the percentage of common stock owned by family members

Independent Directors $=$ proportion of independent directors

Firm Size $=$ natural $\log$ of total assets

Leverage $=$ ratio of financial liabilities to total assets

Market-to-Book = ratio of market value of equity to its book value

Sales Growth = year-to-year percentage change in total sales

Cash Flow $=$ cash flow from operation, scaled by lagged total assets

Institution Ownership = institutional ownership based on the percentage of common stock owned by institutional shareholders

CEO Duality $=$ one if a CEO serves as the chairman of the board, zero otherwise.

White-adjusted t-statistics are in parentheses.

$*$ p. 10

$* *$ p .05

$* * *$ p. 01

\section{Inter-quantile Comparisons of the Effects of Family Ownership and Independent Directorship}

To check the significance of the differences of Family Ownership and Independent Directors coefficients across different earnings management quantiles, we employ a bootstrap method to test various pairs of quantiles (Kuan, Li, \& Liu, 2012; Li, Sun, \& Zou, 2009). The bootstrap method can be used to derive the variance-covariance matrix of the regression parameter and thus obtain estimated standard errors for the coefficients. Therefore, the bootstrap method can provide us with a statistical comparison (F-tests) of regression coefficients on Family Ownership and Independent Directors across different quantiles. In our estimations, F-tests are based on 1,000 bootstrap replications. Table 3 shows that the coefficient differences of Family Ownership in terms of the lower 10th and 25th quantiles versus the upper 75th and 90th quantiles, respectively, are statistically significant. Independent Directors, presented in Table 4, obtains similar results. The results of the F-tests suggest significant differences across lower and upper quantiles, with the exception of (25th, 90th). These findings indicate that the impacts of family ownership and the proportion of independent directors on earnings management differ between firms with high and low earnings management.

TABLE 3

INTER-QUANTILE COMPARISONS OF THE COEFFICIENT OF FAMILY OWNERSHIP

\begin{tabular}{|c|c|c|c|c|c|}
\hline & \multicolumn{5}{|c|}{ Quantile regressions } \\
\hline & $10^{\text {th }}$ quant & $25^{\text {th }}$ quant & $50^{\text {th }}$ quant & $75^{\text {th }}$ quant & $90^{\text {th }}$ quant \\
\hline $10^{\text {th }}$ quant & & $\begin{array}{l}0.91 \\
(0.339)\end{array}$ & $\begin{array}{l}2.26 \\
(0.133)\end{array}$ & $\begin{array}{l}4.83 * * \\
(0.028)\end{array}$ & $\begin{array}{l}5.04 * * \\
(0.025)\end{array}$ \\
\hline $25^{\text {th }}$ quant & & & $\begin{array}{l}1.74 \\
(0.187)\end{array}$ & $\begin{array}{l}5.29 * * \\
(0.022)\end{array}$ & $\begin{array}{l}4.19 * * \\
(0.041)\end{array}$ \\
\hline $50^{\text {th }}$ quant & & & & $\begin{array}{l}3.53^{*} \\
(0.060)\end{array}$ & $\begin{array}{l}2.80^{*} \\
(0.094)\end{array}$ \\
\hline $75^{\text {th }}$ quant & & & & & $\begin{array}{l}0.77 \\
(0.380)\end{array}$ \\
\hline
\end{tabular}

P-values are reported in parentheses, below each F-test.

$*$ p .10

$* *$ p .05

$* * *$ p. 01 
TABLE 4

INTER-QUANTILE COMPARISONS OF THE COEFFICIENT OF INDEPENDENT DIRECTORS

\begin{tabular}{|c|c|c|c|c|c|}
\hline & \multicolumn{5}{|c|}{ Quantile regressions } \\
\hline & $10^{\text {th }}$ quant & $25^{\text {th }}$ quant & $50^{\text {th }}$ quant & $75^{\text {th }}$ quant & $90^{\text {th }}$ quant \\
\hline $10^{\text {th }}$ quant & & $\begin{array}{l}10.09 * * * \\
(0.002)\end{array}$ & $\begin{array}{l}13.73 * * * \\
(0.000)\end{array}$ & $\begin{array}{l}14.50 * * * \\
(0.000)\end{array}$ & $\begin{array}{l}3.18^{*} \\
(0.075)\end{array}$ \\
\hline $25^{\text {th }}$ quant & & & $\begin{array}{l}3.51 * \\
(0.061)\end{array}$ & $\begin{array}{l}4.35^{* *} \\
(0.037)\end{array}$ & $\begin{array}{l}0.00 \\
(0.997)\end{array}$ \\
\hline $50^{\text {th }}$ quant & & & & $\begin{array}{l}1.03 \\
(0.309)\end{array}$ & $\begin{array}{l}0.65 \\
(0.419)\end{array}$ \\
\hline $75^{\text {th }}$ quant & & & & & $\begin{array}{l}2.03 \\
(0.155) \\
\end{array}$ \\
\hline
\end{tabular}

P-values are reported in parentheses, below each F-test.

$*$ p .10

$* *$ p .05

$* * *$ p. 01

To provide further insight into the effects of family ownership and the proportion of independent directors across the quantiles in the conditional distribution of firm earnings management, we plot the coefficients of Family Ownership and Independent Directors along the vertical axis and the quantiles along the horizontal axis, respectively. The solid line reflects the coefficient estimate of the quantile regression in different quantiles, and the shaded grey area indicates its corresponding $95 \%$ confidence intervals. The dashed horizontal line is the fixed-effect estimate of the mean earnings management. As shown in Figure 1, all coefficients of the quantile regression are lower than the estimate from the fixedeffect regression. The quantile regression estimates of Family Ownership are significantly positive in lower and median quantiles, but they are not significant in the upper quantiles. In addition, quantile effects are stronger in lower quantiles. Independent Directors, presented in Figure 2, shows that all coefficients of the quantile regression are higher than the estimate from the fixed-effect regression. The quantile regression estimates of Independent Directors are significantly negative in lower quantiles but insignificant in median and upper quantiles. Similarly, quantile effects are stronger in lower quantiles. 
FIGURE 1

QUANTILE AND FIXED-EFFECT ESTIMATES OF THE EFFECTS OF FAMILY OWNERSHIP ON EARNINGS MANAGEMENT

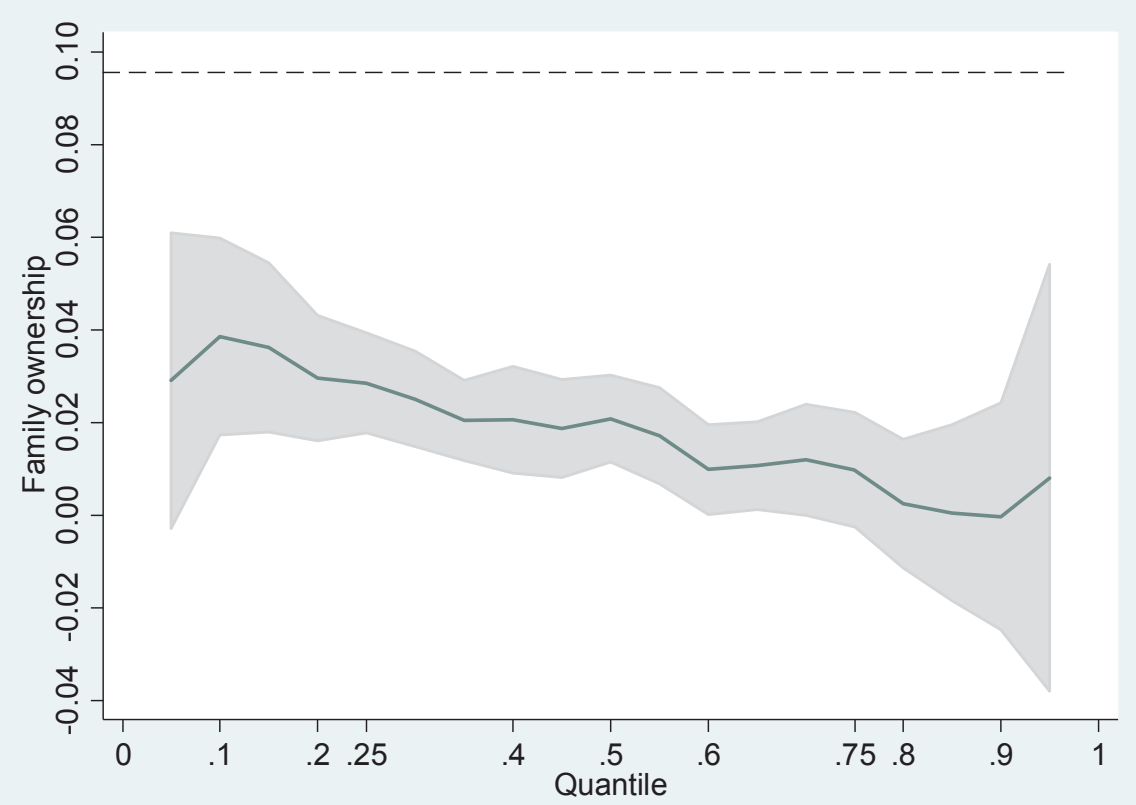

FIGURE 2

QUANTILE AND FIXED-EFFECT ESTIMATES OF THE EFFECTS OF INDEPENDENT DIRECTORS ON EARNINGS MANAGEMENT

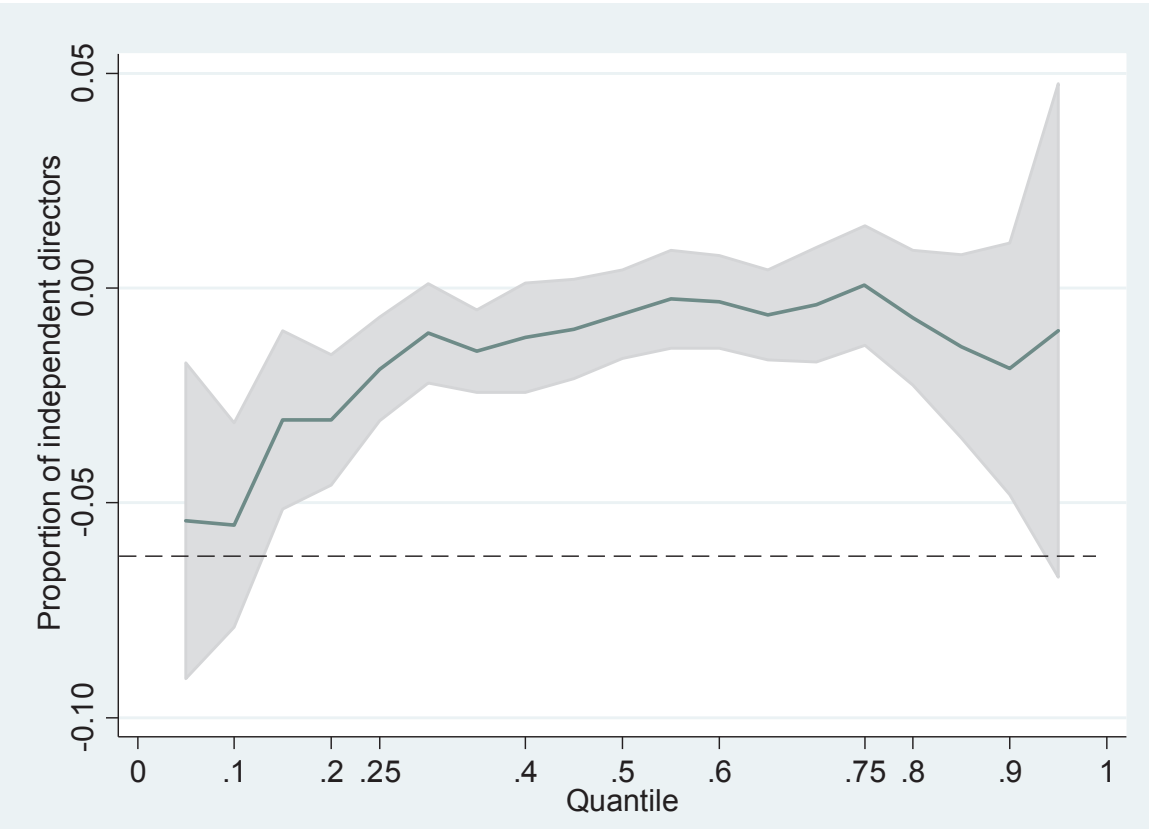




\section{CONCLUDING REMARKS}

This study examines the impact of family ownership and the proportion of independent directors on earnings management behavior in Taiwan, where concentrated ownership and weak legal systems are prevalent. Prior empirical evidence on the relationship between family ownership and earning management is inconclusive when assessed using conditional mean regression. Therefore, we employ the quantile regression model to generate different estimates at conditional quantiles in order to completely observe the relationship.

Our empirical results show that the various coefficients obtained from different quantile regression models of earnings management. The quantile estimated coefficients of family ownership are significantly positive when the levels of earnings management are low and median, whereas those from the high levels of earnings management are not. The positive coefficients support the entrenchment effects by family owners, in line with agency theory, which states that an increase in family ownership will increase owners' ability to engage in earnings management behavior. When levels of earnings management are high, though, entrenched owners effectively control the firm. Increased family ownership cannot further entrench the controlling owners to manipulate reported earnings to pursue their own interests. Furthermore, we find that a higher proportion of independent directors does effectively reduce earnings management behavior in firms with low earnings management. For firms with high earnings management, the insignificance of the proportion of independent directors may be that the likelihood of entrenchment effects is larger in such firms. Controlling owners prefer to arrange more affiliated board members to entrench their board control, consequently mitigating the board's oversight function.

This paper uses a quantile regression method to provide a new explanation for differing past empirical results regarding the relationship between corporate governance and earnings management. Our finding that the effectiveness of family ownership and board independence on earnings management depend on the level of firm earnings management may lead regulators and academics to take into account the differential forces of family ownership among firms and carefully consider the implications for the independence of directors. Our results suggest that, to protect shareholders' best interests, regulators should pay special attention to the social networks between independent directors and family members.

This study focuses only on Taiwan's institutional system. Because institutional backgrounds and regulatory environments vary, we cannot assume that the results can be readily generalized to other emerging countries. Therefore, a fruitful direction for future research would be a comparison of earnings quality of family-controlled firms across other East Asian countries with the goal of reaching more general conclusions.

\section{ENDNOTES}

* This is an invited article. We appreciate the kind invitation by the Journal editor for submission. Nonetheless, we are fully responsible for any errors or omissions remaining. College of Business University of Southern Mississippi 118 College Drive, \#5076 Hattiesburg, MS 39406, Email: shinhua.liu@usm.edu Tel: (601) 266-6655

1. School of Management Ming Chuan University Taipei, Taiwan, Email: wenchi@mail.mcu.edu.tw

2. Sanchez School of Business Texas A\&M International University Laredo, TX 78041, Email: ken.hung@tamiu.edu

\section{REFERENCES}

Anderson, R. C., \& Reeb, D. M. (2004). Board composition: Balancing family influence in S\&P 500 firms. Administrative Science Quarterly, 49, 209-237.

Ashbaugh, H., LaFond, R., \& Mayhew, B. W. (2003). No nonaudit services compromise auditor independence? Further evidence. The Accounting Review, 78, 611-639. 
Barnes, M. L., \& Hughes, A. W. (2002). A quantile regression analysis of the cross section of stock market returns. Working Paper, Federal Reserve Bank of Boston.

Beasley, M. (1996). An empirical analysis of the relation between the board of director composition and financial statement fraud. The Accounting Review, 71, 443-465.

Chaney, P. K., Faccio, M., \& Parsley, D. (2011). The quality of accounting information in politically connected firms. Journal of Accounting and Economics, 51, 58-76.

Chen, I. J. (2014). Financial crisis and the dynamics of corporate governance: Evidence from Taiwan's listed firms. International Review of Economics and Finance, 32, 3-28.

Chen, M. Y. (2014). Determinants of corporate board structure in Taiwan. International Review of Economics and Finance, 32, 62-78.

Chen, Y. R., \& Ho, C. Y. (2009). The impact of family control and board characteristics on corporate policies. Journal of Management, 26,1-16.

Chen, S. S., \& Huang, Y. S. (2014). Corporate governance in emerging markets: An introduction. International Review of Economics and Finance, 32, 1-2.

Chen, S. K., Lin, B. X., Wang, Y., \& Wu, L. (2010). The frequency and magnitude of earnings management: Time-series and multi-threshold comparisons. International Review of Economics and Finance, 19, 671-685.

Chen, K. Y., \& Liu, Jo-L. (2010). Earnings management, CEO domination, and growth opportunities: Evidence from Taiwan. International Journal of Public Information Systems, 58, 43-69.

$\mathrm{Chu}, \mathrm{W}$. (2011). Family ownership and firm performance: Influence of family management, family control, and firm size. Asia-Pacific Journal of Management, 28, 833-851.

Cueto, D. C. (2013). Substitutability and complementarity of corporate governance mechanisms in Latin America. International Review of Economics and Finance, 25, 310-325.

Davids, J. H., Schoorman, F. D., \& Donaldson, L. (1997). Toward a stewardship theory of management. Academy of Management Review, 22, 20-47.

Fama, E. (1980). Agency problems and the theory of the firm. Journal of Political Economy, 88, 288-307.

Fama, E., \& Jensen, M. (1983). Separation of ownership and control. Journal of Law and Economics, 26, 301-325.

Fan, J., \& Wong, T. J. (2002). Corporate ownership structure and the informativeness of accounting earnings in East Asia. Journal of Accounting and Economics, 33, 401-425.

Filatotchev, I., Lien, L. P., \& Piesse, J. (2005). Corporate governance and performance in publicly listed, family-controlled firms: Evidence from Taiwan. Asia-Pacific Journal of Management, 22, 257283.

Fracassi, C., \& Tate, G. (2012). External networking and internal firm governance. Journal of Finance, 67, 153-194.

Gebka, B., \& Wohar, M. E. (2013). Causality between trading volume and returns: Evidence from quantile regressions. International Review of Economics and Finance, 27, 144-159.

Haw, I., Ho, S. S.M., \& Li, A. Y. (2011). Corporate governance and earnings management by classification shifting. Contemporary Accounting Research, 28, 517-553.

Harford, J., Mansi, S. A., \& Maxwell, W. F. (2008). Corporate governance and firm cash holdings in the US. Journal of Finance Economics, 87, 535-555.

Huang, H. H., \& Chan, M. L. (2013). The initial private placement of equity and changes in operating performance in Taiwan. Accounting and Finance, 53, 711-730.

Islam, M. A., Ali, R., \& Ahmad, Z. (2011). Is modified Jones Model effective in detecting earnings management? Evidence from a developing economy. International Journal of Economics and Finance, 3, 116-125.

Jensen, M. C. (1993). The modern industrial revolution, exit, and the failure of internal control systems. The Journal of Finance, 48, 831-880.

Jensen, M., \& Meckling, W. (1976). Theory of the firm: Managerial behavior, agency costs and ownership structure. Journal of financial Economics, 3, 305-360. 
Keonker, R., \& Hallock, K. F. (2001). Quantile regression. Journal of Economic Perspectives, 15, $143-$ 156.

Klein, A. (2002). Audi committee, board of director characteristics and earnings management. Journal of Accounting and Economics, 33, 375-400.

Kothari, S. P., Leone, A. J., \& Wasley, C. E. (2005). Performance matched discretionary accrual measures. Journal of Accounting and Economics, 39, 163-197.

Kuan, T. H., Li, C. S., \& Liu, C. C. (2012). Corporate governance and cash holdings: A quantile regression approach. International Review of Economics and Finance, 24, 303-314.

La Porta, R., Lopez-De-Silanes, F., \& Shleifer, A. (1999). Corporate ownership around the world. Journal of Finance, 54, 471-517.

Leuz, C. (2006). Cross listing, bonding and firms' reporting incentives: a discussion of Lang, Ready and Wilson (2006). Journal of Accounting and Economics, 42, 285-299.

Leuz, C., Nanda, D., \& Wysocki, P. D. (2003). Earnings management and investor protection: An international comparison. Journal of Financial Economics, 69, 505-527.

Li, T., Sun, L., \& Zou, L. (2009). State ownership and corporate performance: A quantile regression analysis of Chinese listed companies. China Economic Review, 20, 703-716.

Mak, Y. T., \& Li, Y. (2001). Determinants of corporate ownership and board structure: evidence from Singapore. Journal of Corporate Finance, 7, 235-256.

Miller, D., \& Le Breton-Miller, I. (2006). Family governance and firm performance: Agency, stewardship, and capabilities. Family Business Review, 19(1), 73-87.

Morck, R., \& Yeung, B. (2003). Agency problems in large family business groups. Entrepreneurship Theory and Practice, 27, 367-382.

Peasnell, K. V., Pope, P. F., \& Young, S. (2003). Managerial equity ownership and the demand for outside directors. European Financial Management, 9(2), 231-250.

Prencipe, A., \& Bar-Yosef, S. (2011). Corporate governance and earning management in familycontrolled companies. Journal of Accounting, Auditing and Finance, 26, 199-227.

Prencipe, A., Markarian, G., \& Pozza, L. (2008). Earnings management in family firms: Evidence from R\&D cost capitalization in Italy. Family Business Review, 21, 71-88.

Ramdani, D., \& Witteloostuijn, A. (2010). The impact of board independence and CEO duality on firm performance: A quantile regression analysis for Indonesia, Malaysia, South Korea and Thailand. British Academy of Management, 21, 607-626.

Shu, P. G, \& Chiang, S. J. (2014). Firm size, timing, and earnings management of seasoned equity offerings. International Review of Economics and Finance, 29: 177-194.

Shyu, Y. W., \& Lee, C. I. (2009). Excess control rights and debt maturity structure in family-controlled firms. Corporate Governance: An International Review, 17, 611-628.

Wang, D. (2006). Founding family ownership and earnings quality. Journal of Accounting Research, 44, 619-656.

Wang, J. Y. (2014). Controlling shareholder entrenchment: Bonuses versus dividends. International Review of Economics and Finance, 32, 143-158.

Xie, B., Davidson, W. N., \& DaDalt, P. J. (2003). Earnings management and corporate governance: The role of the board and audit committee, Journal of Corporate Finance, 9, 295-316.

Yeh,Y.H., Lee, T.S., \& Woidtke, T. (2001), Family control and corporate governance: Evidence for Taiwan, International Review of Finance, 2, 21-48

Yeh, Y., \& Woidtke, T. (2005). Commitment or entrenchment? Controlling shareholders and board composition. Journal of Banking \& Finance, 29, 1857-1885.

Yoshikawa, T., \& Rasheed, A. A. (2010). Family control and ownership monitoring in family-controlled firms in Japan. Journal of Management Studies, 47, 274-295.

Young, M. N., Peng, M. W., Ahlstrom, D., Bruton G. D., \& Jiang, Y. (2008). Corporate governance in emerging economies: A review of the principal-principal perspective. Journal of Management Studies, 45(1), 196-220. 